\title{
Production of Bioethanol Fuel from Low-Grade-Date Extract
}

\author{
A. K. Sulieman, M. H. Gaily, M. A. Zeinelabdeen, M. D. Putra, and A. E. Abasaeed
}

\begin{abstract}
Experiments on production of bioethanol through anaerobic fermentation of sugars extracted from low-quality dates using a wild strain of Saccharomyces cerevisiae were conducted at $30^{\circ} \mathrm{C}$ and $33^{\circ} \mathrm{C}$. The effect of the $\mathrm{pH}$ during fermentation was insignificant at the operating temperatures.The average ethanol yield for all experiments was greater than $71 \%$ of its theoretical value. Experiments in a $1 \mathrm{~L}$ volume fermentor at $30^{\circ} \mathrm{C}$ and $120 \mathrm{rpm}$ without controlling the pH during fermentation gave ethanol yields of $91.3 \%, 68.7 \%$ and $54.8 \%$ for the 10,15 and $20 \%$ initial sugar concentrations, respectively. The drop in ethanol yield for $20 \%$ sugars could be attributed to probable ethanol inhibition.
\end{abstract}

Index Terms-Bioethanol, Saccharomyces cerevisiae, dates, fermentation

\section{INTRODUCTION}

Bioethanol production has been of great interest worldwide due to intensive demand forthe depleting fossil oil. Also, the high increase of fossil oil prices in the last few years and the increasedawareness of environmental problems related to greenhouse gasesprompted a serious search for an alternative energy source that is sustainable and economically competitive to be used as a fuel.

The attractiveness of ethanol as a motor fuel derives from the fact that it: has high heating value per gallon (about $2 / 3$ that of gasoline); can be blended up to $10 \%$ with gasoline without changing retuning the engine or increasing emission; enhances the octane rating of unleaded gasoline [1]; and could provide asecure source for national energy independence [2].

Production of bioethanol has been continually increasing during the last few years and has reached around 88.7 billion liters in 2011, thus, replacing the need for one million barrels of crude oil per day worldwide; over $90 \%$ of the total world bioethanol is produced in America [3], [4] (see Table I).

Uses of bioethanol are not limited to being an energy substitute or a transportation fuel; they extend to include a wide-band of chemical industries, such as production of acetaldehydes and acetic acid and their derivatives. 95\% ethanol is used pharmaceutical and medical purposes.

The first generation of bioethanol was produced from natural crops, e.g., cereal crops (wheat and maize) and sugar crops (sugar cane, sweet sorghum and sugar beet); while

Manuscript received April 10, 2013; revised June 1, 2013. This work was supported in part by the National Science, Technology and Innovation Plan (NSTIP) at King Saud University under Grant 08-ADV391-02. A. E. Abasaeed is the corresponding author.

The authors are with the Chemical Engineering Department, King Saud University, PO Box 800, Riyadh 11421, Saudi Arabia (e-mail: ashraf08@ksu.edu.sa, mgaily@ksu.edu.sa, mazaaam@yahoo.com, mputra@ksu.edu.sa, abasaeed@ksu.edu.sa). lignocellulosic biomass was the raw material for the second generation. A valid argument for the switch relates to competition between food and energy. This situation produces more challenges for the bioethanol industry. Agricultural wastes (agrowastes) were considered one of these sources that serve dual purpose of waste disposal (an environmental concern) and production of biofuel (an energy concern). Rice straw, wheat straw, corn straw and bagasse were considered the four major agrowastes feed-stocks for bioethanol production due to their availability throughout the year [5]. The conventional technique of producing bioethanol is by yeast fermentation of sugars under certain conditions or by hydrolysis of grain to glucose followed by yeast fermentation [6]. Other bio-resources such as apple pomaces [7] and mahula (MahucaLatifolia) flowers [8] have been also used.

TABLE I: WORLD PRODUCTION OF ETHANOL FUEL IN MILLION LITERS

\begin{tabular}{lrrrrrr}
\hline \hline & 2006 & 2007 & 2008 & 2009 & 2010 & 2011 \\
\hline Europe & 1627 & 1882 & 2814 & 3683 & 4615 & 5467 \\
Africa & 0 & 49 & 72 & 108 & 165 & 170 \\
America & 35625 & 45467 & 60393 & 66368 & 77800 & 79005 \\
Asia/Pacific & 1940 & 2142 & 2743 & 2888 & 3183 & 4077 \\
World & 39192 & 49540 & 66022 & 73047 & 85763 & 88719 \\
\hline \hline \multicolumn{7}{l}{ Source: The Global Renewable Fuels Alliance (GRFA, 2011) }
\end{tabular}

Dates fruit is a suitable resource for bioethanol production. They contain considerable amounts of inverted sugars (glucose and fructose); the two sugars are present in dates in an almost equal amount. The flesh of dates contains about 70 to $75 \%$ sugars [9]. A second-grade (or low-grade) dates showed the same sugar content as dates of high quality [10].

Fermentation of sugars is an anaerobic biological process in which sugars are converted to alcohol by the action of microorganisms, usually yeast [11]. Saccharomyces cerevisiae is the most popular industrial microorganism used for sugar fermentation to produce bioethanol, because it utilizes cheap materials for growth and production. This organism has been already accepted as non-pathogenic, safe producer, which can be easily manipulated genetically and grown on simple and cheap media compared to that of animal cell cultivation [12].

Fermentation of sugar by the yeast Saccharomyces cerevisiae was carried out in an immobilized cell reactor (ICR) to improve the performance of the fermentation process for production of ethanol and to facilitate the separation of cells from the final product [13]. Other researchers used different types of microorganisms at different conditions to produce ethanol, e.g., wild-type strains of yeast Hansenulapolymorpha to ferment glucose, cellobiose and xylose to ethanol [14]; bioethanol production from 
Yarrowialipolytica biomass [15]; bioethanol production by mangrove-derived marine yeast Saccharomyces cerevisiae [16]; production of ethanol from wheat straw hemicellulose acid hydrolysate using an adapted and parent strain of Pichiastipitis,[17]; use of strains of Pichiastipitis and Candidashehatae in fermenting a mixture of glucose and fructose, [18]; and the semi-continuous ethanol production from whey with co-immobilized enzyme and Saccharomyces cerevisiae followed by pervaporation of product,[19].

The main objective of this study is the production of bioethanol from low-grade-date extract using wild strain Saccharomyces cerevisiae yeast.

\section{MATERIALS AND Methods}

Low grade, unclassified as a dates' variety that is considered as wastes and usually used as animal fodder has been used to prepare the substrate for this study.

Sugars in dates were extracted by using deionized water at $40^{\circ} \mathrm{C}$ for two hours to prepare the substrate for the fermentation. Fibers and free suspended solid in date extract were removed by centrifugation at $5000 \mathrm{rpm}$ in a centrifuge (Model VarifugeF- Heraeussepatech D-6072 from Karl-Kolb) for 5 minutes and then filtered through a Whatmann filter paper. Clear date extract was decanted and collected in a 1000 $\mathrm{ml}$ Erlenmeyer flask. Three different initial sugar concentrations of 10,15 and $20 \mathrm{~g} / 100 \mathrm{ml}$ (referred to as 10,15 and $20 \%$ respectively in the paper) were prepared and sterilized in autoclave (Astel AMB230N) at $121^{\circ} \mathrm{C}$ for 15 minutes.

Wild strain Saccharomyces cerevisiae yeast (STAR brand; used in the bakery industry) obtained from the local market was used. The yeast was activated in a Malt Yeast Peptone Glucose broth (MYPG Broth). The MYPG broth was prepared by dissolving $1.5 \mathrm{~g}$ malt extract, $1.5 \mathrm{~g}$ yeast extract, $2.5 \mathrm{~g}$ peptone and $5 \mathrm{~g}$ dextrose in $500 \mathrm{ml}$ of deionized water. The $\mathrm{pH}$ of the broth was recorded and adjusted to 4.5 by adding few drops of $1 \mathrm{~N} \mathrm{HCl}$ at $25^{\circ} \mathrm{C}$. The MYPG Broth was then sterilized in an autoclave for 15 minutes at $121^{\circ} \mathrm{C}$. 0.2 grams of the yeast, Saccharomyces cerevisiae were activated in $100 \mathrm{ml}$ of MYPG broth in a $400 \mathrm{ml}$ Erlenmeyer flask at $30^{\circ} \mathrm{C}$ and $120 \mathrm{rpm}$ for 24 hours. A $1 \mathrm{~L}$ total volume fermentor (Minifore Lambda) supported with FNet software was used in the fermentation experiments.

Ethanol as well as sugars in date extract were analyzed by a High Performance Liquid Chromatograph, HPLC (Agilent 1200 Infinitely series) equipped with RID detector and Aminex ${ }^{\circledR}$ column, $150 \times 7.8 \mathrm{~mm}$ (Cat. \#125-0115) from BIO-RAD was used. The column was maintained at $40^{\circ} \mathrm{C}$ and $1 \mathrm{mM}$ sulfuric acid solution was used as a mobile phase for the analysis at flow rate of $0.8 \mathrm{ml} / \mathrm{min}$.

Two sets of fermentation experiments were conducted at a constant date extract final concentration of $13.43 \%$ at $30^{\circ} \mathrm{C}$ and $33^{\circ} \mathrm{C}$ to study the effect of $\mathrm{pH}$ during the fermentation. The first set was run without controlling the $\mathrm{pH}$ during fermentation process while the other set was made with controlling and re-adjusting the $\mathrm{pH}$ during fermentation to its initial value. For both sets an initial $\mathrm{pH}$ was 4.5 .

Different sets of experiments were conductedusing the three different concentrations of substrate (i.e., 10, 15 and $20 \%$ ). The substrate was loaded in the fermentor vessel and all openings and connections of the vessel were tightly closed. The fermentor vessel with its contents were sterilized at $121^{\circ} \mathrm{C}$ for $15 \mathrm{~min}$ in autoclave (Astel AMB230N), and then the vessel was connected to the fermentor body. Yeast was then aseptically transferred to the fermentor. Fermentation experiments were performed at $30^{\circ} \mathrm{C}$ using a constant agitation speed of $120 \mathrm{rpm}$. The total working volume was $400 \mathrm{ml}$.

\section{RESUlTS AND DisCUSSIONS}

Nutrition requirements for the Saccharomyces cerevisiae to generate energy and cellular synthesis such as carbon source, nitrogen source in addition to essential minerals and vitamins are present in the composition of date extracts. Other factors such as $\mathrm{pH}$, temperature and initial sugar concentrations also affect the mechanism of ethanol production through the fermentation process.

\section{A. $p H$ Effect}

Two sets of experiments were conducted with and without controlling the $\mathrm{pH}$ during fermentation. Results of both sets were illustrated in Fig. 1 and Fig. 2. Results on the effect of $\mathrm{pH}$ at $30^{\circ} \mathrm{C}$ and $33^{\circ} \mathrm{C}$ during fermentation of date extract are illustrated in Table II.

The results show that the ethanol yield at $30^{\circ} \mathrm{C}$ was found to be 71.6 and $73.2 \%$ with and without controlling the $\mathrm{pH}$, respectively during the fermentation process with a slight increase in the final ethanol yield and concentration. At $33^{\circ} \mathrm{C}$ higher ethanol yields were obtained for the two cases with values of 78.4 and $84.6 \%$, respectively.

TABLE II: ETHANOL YIELD AND CONCENTRATION OF PH CONTROLLED AND UNCONTROLLED PH AT 30 AND $33^{\circ} \mathrm{C}$ FERMENTATION TEMPERATURES

\begin{tabular}{lcccl}
\hline \hline Ethanol & $\left(30^{\circ} \mathrm{C}\right)^{(\mathrm{a})}$ & $\left(30^{\circ} \mathrm{C}\right)^{(\mathrm{b})}$ & $\left(33^{\circ} \mathrm{C}\right)^{(\mathrm{a})}$ & $\begin{array}{l}\left(33^{\circ} \mathrm{C}\right) \\
(\mathrm{b})\end{array}$ \\
\hline Yield (\%) & 71.6 & 73.2 & 78.4 & 84.6 \\
Conc. $(\mathrm{g} / 100 \mathrm{ml})$ & 4.90 & 4.96 & 4.85 & 5.36 \\
\hline \hline
\end{tabular}

(a) $\mathrm{pH}$ controlled (b) $\mathrm{pH}$ Uncontrolled

The final ethanol concentration was found to be lower for experiments with controlled $\mathrm{pH}$ due to dilution. On the other hand, ethanol yields during fermentation period showed higher values at $30^{\circ} \mathrm{C}$ compared to that at $33^{\circ} \mathrm{C}$ (see Fig. 1) although the final yield at the end of fermentation is higher at $33^{\circ} \mathrm{C}$.

Fig. 2 shows sugar consumption profiles during fermentation. Sugars are completely consumed after 24 hours fermentation time at $30^{\circ} \mathrm{C}$. It could be concluded from Table II and from Fig. 1 and Fig. 2, the effect of $\mathrm{pH}$ during fermentation at 30 and $33^{\circ} \mathrm{C}$ is insignificant. Higher ethanol yields were obtained at $33^{\circ} \mathrm{C}$ andinsignificant amount of sugars were left unfermented.

\section{B. Effect of Initial Sugar Concentration}

Fermentation experiments at different initial sugar concentrations of 10,15 and $20 \%$ and at $30^{\circ} \mathrm{C}$ and $120 \mathrm{rpm}$ were carried out using Saccharomyces cerevisiae wild yeast 
strain.

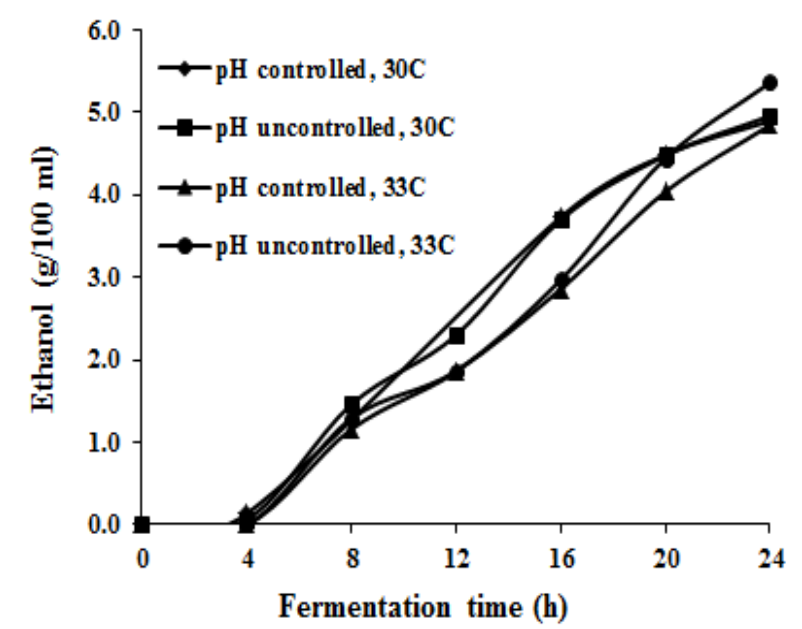

Fig. 1. Ethanol profiles of controlled and non-controlled $\mathrm{pH}$ fermentations at $30^{\circ} \mathrm{C}$ and $33^{\circ} \mathrm{C}$

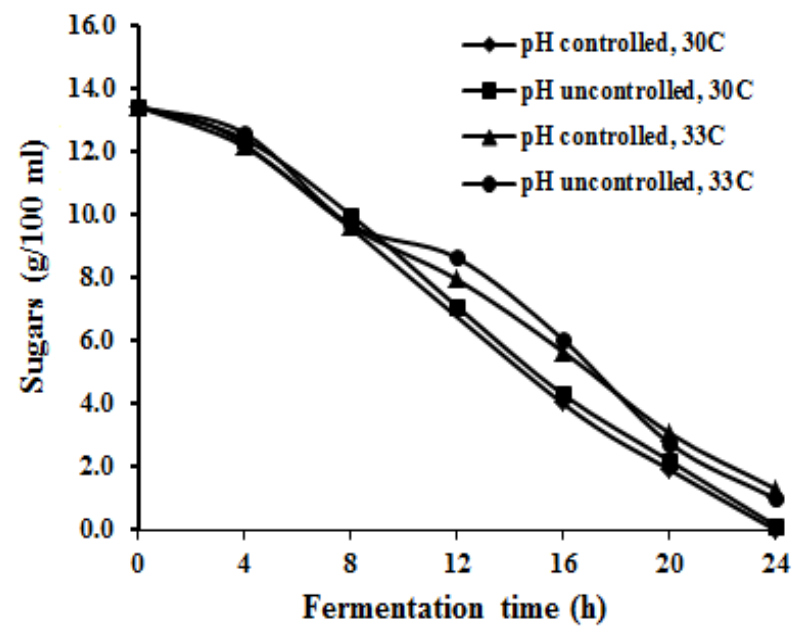

Fig. 2. Sugar consumption profiles of controlled and uncontrolled $\mathrm{pH}$ fermentations at $30^{\circ} \mathrm{C}$ and $33^{\circ} \mathrm{C}$

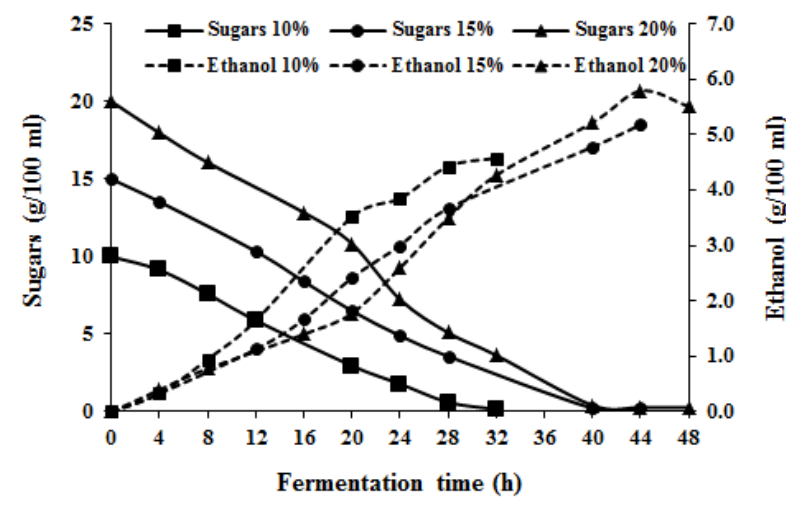

Fig. 3. Sugars and ethanol profiles during fermentation at $30^{\circ} \mathrm{C}$

Sugar profiles as well as the ethanol produced during fermentation were shown in Fig. 3. The 10\% initial sugar concentrations date extract was completely fermented in 32 hproducing $4.58 \mathrm{~g} / 100 \mathrm{ml}$ ethanol with ethanol yield of $91.3 \%$ of the theoretical (see Table III). On the other hand, more fermentation time, 44 and $48 \mathrm{~h}$ are needed for complete fermentation for initial sugar concentration of date extract of 15 and $20 \%$ resulting in final ethanol concentrations of 5.10 and $5.51 \mathrm{~g} / 100 \mathrm{ml}$ and ethanol yields of 68.7 and $54.8 \%$, respectively (see Table III). Lower ethanol yield was obtained for $20 \%$ concentration compared to the other two concentrationsas shown in Fig. 4. A probable explanation of this could be relatedto ethanol inhibition. It is clear that from Fig. 4 that higher ethanol yield rates during fermentation is obtained with date extract concentration of $10 \%$. Working at lower concentration results in higher ethanol yields and less fermentation time.

TABLE III: ETHANOL YIELD AND CONCENTRATION DURING FERMENTATIONS AT $30^{\circ} \mathrm{C}$ AND UNCONTROLLED PH OF DIFFERENT INITIAL SUGAR CONCENTRATIONS

\begin{tabular}{lccc}
\hline \hline Initial sugar concentrations & $10 \%$ & $15 \%$ & $20 \%)$ \\
\hline Ethanol yield, \% & 91.3 & 68.7 & 54.8 \\
Ethanol concentration, g/100 ml & 4.58 & 5.10 & 5.51 \\
\hline \hline
\end{tabular}

\section{CONCLUSIONS}

Dates as well as low-grade-dates are rich of sugars, mainly glucose and fructose which can be converted to ethanol and can also serve as essential carbon sources for yeast growth. Other nutrients, minerals and vitamins are also present within date's constituents which enhance the fermentation process to produce bioethanol. Many factors, such as temperature and initial sugar concentrations can affect the whole process. $\mathrm{pH}$, within a reasonable range, was shown to have minor effects bioethanol production. Ethanol yields $>71 \%$ were obtained at controlled and uncontrolled $\mathrm{pH}$ experiments. Ethanol yields of $91.3 \%, 68.7 \%$ and $54.8 \%$ were obtained from the $10 \%$, $15 \%$ and $20 \%$ initial sugar concentration. Ethanol inhibitionscould explains the drop of ethanol yields at higher sugar concentrations. More studies on bioethanol production from low-grade-date extracts are recommended to enhance the ethanol yield considering the economics of the process.

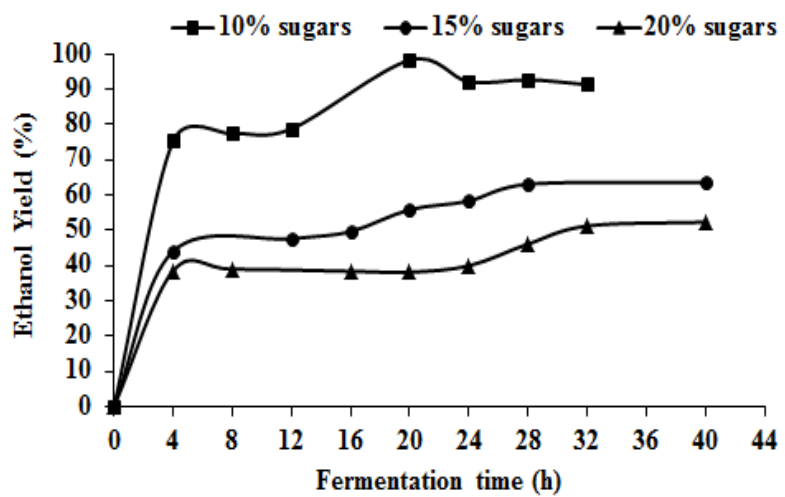

Fig. 4. Ethanol yields at different initial sugar concentrations

\section{ACKNOWLEDGMENT}

The authors extend their appreciation to the National Science, Technology and Innovation Plan (NSTIP) at King Saud University for their generous support and funding of this study as a part of project \# 08-ADV391-02.

\section{REFERENCES}

[1] J. E. Bailey and D. F. Ollis, Biochemical Engineering Fundamentals, $2^{\text {nd }}$ ed, New York, London: McGraw-Hill1986.

[2] M. F. Demirbas and B. Mustafa, "Recent advances on the production and utilization trends of bio-fuels: A global perspective," Energy Conversion and Management, vol. 47, issues 15, pp. 2371-238. September 2006. 
[3] The Global Renewable Fuels Alliance (GRFA). [Online]. Available: http://www.globalrfa.org/pr_021111.php

[4] L. Mojovic, D. Pejin, M. Rakin, J. Pejin, S. Nikolic, and A Djukic-Vukovic, "How to improve the economy of bioethanol production in Serbia," Renewable and Sustainable Energy Reviews, vol. 16, pp. 6040-6047, 2012.

[5] N. Sarkar, S. K. Ghosh, S. Bannerjee, and A. Aikat, "Bioethanol production from Agricultural wastes: An overview," Renewable Energy, vol. 37, pp. 19-27, 2012.

[6] B. Hahn-Hägerdal, M. Galbe, M. F. Gorwa-Grauslund, G. Lidén, and G. Zacchi, "Bio-ethanol - the fuel of tomorrow from the residues of today," Trends in Biotechnology, vol. 24, issue 12, pp. 549-556, 2006.

[7] E. Evcan, C. Tari, and B. Ozen, "Bioethanol production from low cost agro-industrial waste products," New Biotechnology, vol. 295, pp. 40 Poster 1.1.11., 2012

[8] S. K. Mohanty, S. Behera, M. R. Swain, and R. C. Ray, "Bioethanol production from Mahula (Madhucalatifolia L.) flowers by solid-state fermentation," Applied Energy, vol. 86, pp. 640-644, 2009.

[9] M. Elleuch, S. Besbes, O. Roiseux, C. Blecher, C. Deroanne, N. Dirar, and H. Attia, "Date flesh: Chemical composition and characteristics of the dietary fibre," Food Chemistry, vol. 111, pp. 676-682, 2008.

[10] S. Besbes, L. Drira, , C. Blecher, C. Deronne, and H. Attia, "Adding value to hard date (Pheonixdactylifera L.): Compositional, functional and sensory characteristics of date jam," Food Chemistry, vol. 112, pp. 406-411, 2009

[11] A. Demirbas, "Progress and recent trends in biofuels," Progress in Energy and Combustion Science, vol. 33, no. 1, pp. 1-18, 2007.

[12] P. A. Vrsalovic and D. Vasic-Racki, "Modeling of the alcohol dehydrogenase production in baker's yeast," Process Biochemistry, vol 40, no. 8, pp. 2781-2791. 2005.

[13] G. Najafpour, H. Younesi, and K. Ismail, "Ethanol fermentation in an immobilized cell reactor using Saccharomyces cerevisiae," Bioresource Technology, vol. 92, pp. 251-260. 2004.

[14] O. Ryabove, O. Chmil, and A. Sibirny, "Xylose and cellobiose fermentation to ethanol by the thermotolerantmethylotrophic yeast Hansenulapolymorpha," FEMS Yeast Research, vol. 4, pp. 157-164. 2003.

[15] Y. A. Tsigie, W. Chung-Hsan, H. H. Lien, I. Suryadi, and J. Yi-Hsu. (2012). Bioethanol production from Yarrowialipolytica Po1g biomass Bioresour. Technol. [Online]. Available: http://dx.doi.org/10.1016/j.biortech.2012.11.091

[16] K. Saravanakumar, P. Senthilraja, and K. Kathiresan, "Bioethanol production by mangrove-derived marine yeast, Saccharomycescervisiae," Journal of King Saud University - Science, 2013

[17] J. N. Nigam, "Ethanol production from wheat straw hemicellulose hydrolysate by Pichiastipitis," Journal of Biotechnology, vol. 87, pp $17-27,2001$

[18] H. Sreenatha and T. Jeffries, "Production of ethanol from wood hydrolyzate by yeasts," Bioresource Technology, vol. 72, pp. 253-260, 2000.

[19] M. Staniszewski, W. Kujawski, and M. Lewandowska, "Semi-continuous ethanol production from whey with co-immobilized enzyme and yeast cells followed by pervaporative recovery of product - Kinetic model predictions considering glucose repression," Journal of Food Engineering, vol. 91, pp. 240-249, 2009.

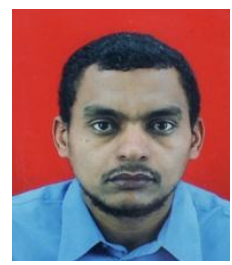

Ashraf K. Sulieman was born in Sudan in 1975. He got his BS and MS from University of Khartoum in 1999 and 2003 respectively. His BS is in Chemical Engineering and his MS in computational Mathematics and its application in Chemical Engineering. He currently serves as a lecturer in the Chemical Engineering Department His current research interests includeselective fermentation and mathematical modeling of reactive systems.

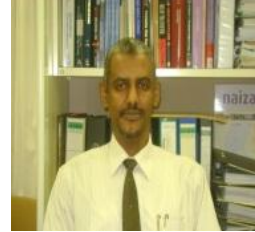

Mohamed H. Gaily was born in Sudan, on $21^{\mathrm{s}}$ November, 1967. He has obtained his Ph. D. degree in Chemical Engineering in the year 2010 from University of Khartoum, Sudan. M. Sc. Degree in Agricultural Process Engineering in the year 1999 from Universiti Putra Malaysia, Malaysia and B. Sc. in Chemical Engineering in 1992 from University of Khartoum, Sudan.He is working as a researcher in Chemical Engineering Department, King Saud University in Saudi Arabia. He also worked as a lecturer at University of Khartoum. He has published several research articles in the field of biochemical engineering. His research interests include selective fermentation and production of biofuels. He registered, with others, a US patent \# 7942972 describing a method of separating fructose and glucose. Dr. Gaily is a member for Saudi Chemical Engineering Society and Saudi Chemical Society. He worked for academic accreditation committee and strategic plan committee for Engineering College at King Saud University, Saudi Arabia.

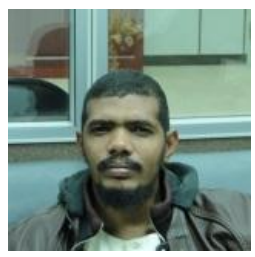

Mohamed A. Zeinelabdeen was born in Sudan. $\mathrm{He}$ got his BSc in Chemical Engineering from Karary Academy of Technology in Sudan (now Karary University) 2003. Worked at Karary University as a teaching assistant from 2003-2010. Eng. Zeinelabdeen Joined King Saud University (Kingdom of Saudi Arabia) as a researcher since 2010. He is currently pursuing an MS degree in Biochemical Engineering at the Chemical Engineering department, King Saud University.

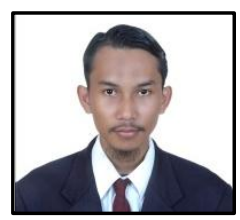

Meilana Dharma Putra was born in 1982 in Indonesia. He obtained a BSc degree from GadjahMada University in 2005, Indonesia. He got his MSc from King Saud University, KSA in 2010 and is now pursuing a $\mathrm{PhD}$ degree in the same University. All degrees are in Chemical Engineering. Since 2006, he has been an official lecturer at LambungMangkurat University, the oldest University in Borneo Island. His research interests include selective fermentation, oxidative dehydrogenation of alkanes and recycling of used lubricating oil. He has contributed over 7 publications.

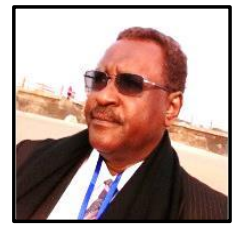

Ahmed E. Abasaeed was born on June, 28, 1954 in Sudan where he got his BS from University of Khartoum, 1978. He got his MS from University of Florida, USA, 1982 and $\mathrm{PhD}$ from Auburn University, USA, 1987. All degrees are in Chemical Engineering with minors in Mathematics (MS) and Environmental Engineering $(\mathrm{PhD})$. He currently serves as a Professor of Chemical Engineering at King Saud University. He previously worked as an Associate Research Professor at the Renewable Energy research Institute in Sudan. His current research interest include selective fermentation, dry reforming of methane and oxidative dehydrogenation of alkanes. Professor Abasaeed has authored over 140 publications, 3 books and 5 US and EU Patents. He has received a number of awards for his academic and research achievements. 